\title{
HAND MUSCLE GRIP STRENGTH ON PRE- AND POST- RUBBER BALL PERFORMING EXERCISES OF OLDER PEOPLE Isabel NA Pangaribuan ${ }^{1)}$, Nunung Nugroho ${ }^{2)}$, Dave G Oenarta ${ }^{3)}$
}

\begin{abstract}
Introduction: The number of older people in Indonesia continues to rise. Aging process will cause changes in organ systems, one of which is changes in the musculoskeletal system. One of the significant weakening of function in the elderly is the degrading strength of the handheld muscles, which resulted in a decrease of functional abilities. One method which can be used to increase hand muscle grip strength is by doing rubber ball exercise.

Aim: To analyze the difference of hand muscle grip strength on pre- and post- performing rubber ball exercises in elderlies at St. Joseph Nursing Home in Surabaya.

Method: This study is a pre-experimental analytic research with one group pretest - posttest design approach. The sampling technique used consecutive sampling, with a total sample of 48 elderlies. The interventions for rubber ball exercises were carried out three times a week for one month. Instruments used for this study were the MMSE and MNA-SF questionnaires. The hand muscle grip strength was measured using the Handgrip Dynamometer. data analysis was done using the SPSS program and the Chi-Square test. Results: The mean total value of the muscle grip strength pre-exercises was $10,8 \pm 3,9 \mathrm{~kg}$. The mean total value of the hand muscle grip strength post exercises was $11,97 \pm 4,08 \mathrm{~kg}$. The data analysis results show that there was a significant difference between pre- and postperforming rubber ball exercises on the elderly at St. Joseph nursing home in Surabaya. $(\mathrm{p}=0,025)$.
\end{abstract}

Conclusion: There is a significant contrast between pre and post-performing rubber ball exercises on the elderly at St. Joseph nursing home in Surabaya.

Keywords: Elderly, rubber ball exercises, hand muscle grip strength

1) Student of Faculty of Medicine, Widya Mandala Catholic University Surabaya, Jl. Kalisari Selatan No.1 Surabaya. Email : Isabelnauli@gmail.com

2) Department of Physical Medicine and Rehabilitation, Faculty of Medicine, Widya Mandala Catholic University Surabaya J1. Kalisari Selatan No. 1 Surabaya

3) Department of Dermatology and Venereology, Faculty of Medicine, Widya Mandala Catholic University Surabaya J1. Kalisari Selatan No. 1 Surabaya 


\section{INTRODUCTION}

According to Government Regulation of the Republic of Indonesia Number 43 of 2004, an older person is those aged more than 60 years old. Elderly population figures in Indonesia are increasing every year. Based on population projection data in Indonesia, it is estimated that the number of elderly people will increase, from 23.66 million people in 2017 , to 27.08 million people in 2020 , to 33.69 million people in 2025 , to 40.95 million people in 2030, and 48.19 million people in 2035. In 2017, East Java was one of the provinces with the most significant number of older people with a percentage of $12.25 \%$. $^{1}$

The aging process results in changes in every system found in the body, one of which is the musculoskeletal system. Morphological changes in the musculoskeletal system cause functional changes in muscles. These include decreased muscle strength, muscle contraction, the endurance of muscles and bones, elasticity, and flexibility of the muscles resulting in limited movement in the body. ${ }^{2}$ One change in function in elderly individuals is atrophy in muscles, resulting in decreased muscle strength. ${ }^{3}$

Decreased muscle strength, one of which is a decrease in handgrip strength, can result in a decrease in functional ability. This can make elderly individuals dependent on others in carrying out daily activities. ${ }^{4}$ The strength of a handgrip decreases with age. According to research conducted by Setiati et al., at Cipto
Mangunkusumo Hospital in Jakarta, the strength of hand-held hands was low in $8 \%$ and limited mobility in $2.8 \%$ from 251 geriatric outpatients. $^{5}$

the increasing number of elderly population will demand greater attention, one of which is related to the impact that will be caused due to changes in the strength of hand grips in elderly individuals. The strength of a handgrip is a simple measure that can be used to assess muscle strength and is influenced by the muscles' activity in the hands and forearms. ${ }^{6}$ The strength of a handgrip is measured quantitatively using a Handgrip Dynamometer. This tool is a simple tool with a size that is relatively small and has extensive normative data.

For that, we need an exercise that can be used to increase hand grips' strength in elderly individuals so that they can help their functional activities. According to Indrawati, one method that can be used is to use a rubber ball. $^{7}$ Ball grip training is a form of active assistive movement through muscle contraction with the help of external forces such as a therapist or mechanical device. ${ }^{8}$ Holding a ball is to maintain bodily functions and prevent complications due to weakness in the upper limb. This gripping exercise is expected to significantly increase the strength of muscles grip, especially in the handgrip area. Based on this background, the researchers are interested in researching the "The Differences in Hand Muscle Grip 
Strength on Pre- and Post-Rubber Ball Performing Exercises of Older People."

\section{METHOD}

This research was pre-experimental research with one group pre- and post-test design. The population in this study were all elderly in the

St. Joseph Nursing Home. The sample of this study were the elderly at the St. Joseph Nursing Home, Surabaya who meet the inclusion and exclusion criteria. The sampling technique used was non-probability sampling, namely, consecutive sampling. The procedure used in this study began by taking respondents' demographic data. An assessment of cognitive function and nutritional status were carried out. Before the rubber ball exercise was carried out, the researchers measured the strength of the respondent's hand-held muscle using a dynamometer handgrip. Rubber ball exercises were carried out three times a week for one month, and ten minutes is eight minutes of exercise and two minutes of rest. Researchers measured the strength of the hand-held muscle strength of the respondent every week, and after the respondent took rubber ball training for one month.

\section{RESULT}

Table 1. Respondent Characteristics

\begin{tabular}{|c|c|c|}
\hline Variable & $\begin{array}{c}\text { Frequency } \\
\text { (n) }\end{array}$ & $\begin{array}{c}\text { Percentage } \\
(\%)\end{array}$ \\
\hline \multicolumn{3}{|l|}{ Age } \\
\hline $60-70 \mathrm{y} / \mathrm{o}$ & 17 & 35,4 \\
\hline $71-80 \mathrm{y} / \mathrm{o}$ & 31 & 64,6 \\
\hline \multicolumn{3}{|l|}{ Gender } \\
\hline Male & 17 & 35,4 \\
\hline Female & 31 & 64,6 \\
\hline \multicolumn{3}{|l|}{ Education Lv. } \\
\hline Elementary & 11 & 22,9 \\
\hline Junior High School & 18 & 37,5 \\
\hline Senior High School & ol 14 & 29,2 \\
\hline Bachelor's Degree & 5 & 10,4 \\
\hline \multicolumn{3}{|l|}{ Occupation } \\
\hline Enterpreneur & 28 & 58,3 \\
\hline Housewife & 11 & 22,9 \\
\hline Teacher & 4 & 8,3 \\
\hline Tailor & 2 & 4,2 \\
\hline etc & 3 & 6,3 \\
\hline \multicolumn{3}{|l|}{ Medical } \\
\hline \multicolumn{3}{|l|}{ History } \\
\hline Mellitus diabetes & 18 & 37,5 \\
\hline Hypertension & 28 & 58,3 \\
\hline Stroke & 2 & 4,2 \\
\hline \multicolumn{3}{|l|}{ Smoking History } \\
\hline Yes & 4 & 8,3 \\
\hline No & 44 & 91,7 \\
\hline \multicolumn{3}{|l|}{ Frequency } \\
\hline Routine & 26 & 54,2 \\
\hline Not a Routine & 22 & 45,8 \\
\hline \multicolumn{3}{|l|}{ MNA-SF } \\
\hline Normal & 15 & 31,3 \\
\hline Malnutrition risk & 33 & 68,8 \\
\hline \multicolumn{3}{|l|}{ MMSE } \\
\hline Normal & 12 & 25,0 \\
\hline $\begin{array}{l}\text { Probable cognitive } \\
\text { impairment }\end{array}$ & 36 & 75,0 \\
\hline
\end{tabular}


Table 2. Results of Handgrip Muscle Strength Measurement

\begin{tabular}{|c|c|c|c|}
\hline \multirow{2}{*}{$\begin{array}{c}\text { Variable } \\
(\mathrm{kg})\end{array}$} & \multicolumn{2}{|c|}{$\operatorname{Avg} \pm$ Std Dev } & \multirow{2}{*}{ Total } \\
\hline & Routine & Not a Routine & \\
\hline $\begin{array}{l}\text { Pretest } \\
\text { handgrip } \\
\text { muscle } \\
\text { strength }\end{array}$ & $11,0 \pm 3,5$ & $10,6 \pm 4,4$ & $10,8 \pm 3,9$ \\
\hline $\begin{array}{l}\text { First week } \\
\text { handgrip } \\
\text { muscle } \\
\text { strength }\end{array}$ & $11,45 \pm 3,51$ & $10,8 \pm 4,45$ & $11,16 \pm 3,94$ \\
\hline $\begin{array}{l}\text { Second } \\
\text { week } \\
\text { handgrip } \\
\text { muscle } \\
\text { strength } \\
\end{array}$ & $11,78 \pm 3,59$ & $11,1 \pm 4,48$ & $11,46 \pm 3,99$ \\
\hline $\begin{array}{l}\text { Three } \\
\text { weeks } \\
\text { handgrip } \\
\text { muscle } \\
\text { strength }\end{array}$ & $12,03 \pm 3,68$ & $11,40 \pm 4,62$ & $\begin{array}{c}11,74 \\
\pm 4,10\end{array}$ \\
\hline $\begin{array}{l}\text { Post-test } \\
\text { handgrip } \\
\text { muscle } \\
\text { strength }\end{array}$ & $12,30 \pm 3,74$ & $11,58 \pm 4,50$ & $11,97 \pm 4,08$ \\
\hline
\end{tabular}

Table 3. Analysis of Differences in Strength in Handgrip Muscles with Rubber Ball Exercises

\begin{tabular}{|c|c|c|c|c|}
\hline \multirow[t]{2}{*}{ Variable } & \multicolumn{2}{|c|}{$\begin{array}{c}\text { The Difference } \\
\text { Between Muscle } \\
\text { Strength Of A Hand } \\
\text { Holding } \\
\text { n (\%) }\end{array}$} & \multirow{2}{*}{\multicolumn{2}{|c|}{$\begin{array}{l}\text { Total } \\
\text { n (\%) }\end{array}$}} \\
\hline & Increase & Decrease & & \\
\hline \multirow{2}{*}{$\begin{array}{l}\text { Rubber } \\
\text { Ball } \\
\text { Practice }\end{array}$} & Routine $\begin{array}{l}20 \\
(76,9)\end{array}$ & $\begin{array}{l}6 \\
(23,1)\end{array}$ & $\begin{array}{l}26 \\
(100)\end{array}$ & \multirow{2}{*}{0,025} \\
\hline & $\begin{array}{ll}\text { Not a } & 10 \\
\text { Routine } & (45,5) \\
\end{array}$ & $\begin{array}{l}12 \\
(54,5)\end{array}$ & $\begin{array}{l}22 \\
(100)\end{array}$ & \\
\hline
\end{tabular}

\section{DISCUSSION}

Based on the chi-square analysis test results, it was found that there was a significant difference between the strength of the handgrip muscles before and after doing rubber ball training in the elderly at the St. Joseph Nursing Home $(p=0.025)$. The results obtained in this study were in agreement with research conducted by Prok, Gessal and Angliadi at Prof. Kandou Manado General Hospital, where there was a significant influence between active 
motion exercises grasping a rubber ball with the strength of hand-held muscles in stroke patients. The study was conducted for one month. The results showed that the average strength of the handgrip muscles before being given a rubber ball training was $10.56 \mathrm{~kg}$, and after being given a rubber ball training, was $14.06 \mathrm{~kg} .{ }^{9}$ According to research conducted by Chaidir and Zuardi in Bukittinggi RSSN, rubber ball training has an effect of increasing muscle strength in the upper limb so that it can increase muscle strength in stroke patients $(\mathrm{p}=0.012 ; \alpha=$ $<0.05) .10$ Muscle training using the method of grasping the ball is a modality for sensory stimulation smooth touch that can suppress the receptors on the body of the 7-thoracic cervical nerve cells, sensory pathways, and affect the sensory cortex. The sensory cortex will affect the motor cortex so that the response occurs by taking action. The motor cortex acts on the anterior spinal cord run through the anterior root in the cervical and lumbosacral regions, and peripheral nerves on its way to the skeletal muscles. Impulses delivered to muscle cells via neuromuscular junctions will affect muscle movements in the upper limb. A movement in the extremities will increase muscle strength and range of motion to increase physical mobility. ${ }^{7,9,10}$

\section{CONCLUSION}

Based on the results of research on the differences in handgrip muscle strength before and after doing rubber ball training in the elderly at the St. Joseph Nursing Home, with a total sample of 48 people, the following conclusions were obtained:

1. The elderly who routinely participate in rubber ball training had an increased in handgrip muscle strength, which is higher by $76.9 \%$, compared to the elderly who did not routinely participate in rubber ball training.

2. There is a significant difference in handgrip muscle strength before and after doing rubber ball exercises in the elderly with a value of $\mathrm{p}=0.025$.

\section{REFERENCES}

1. Kementerian Kesehatan RI. Pusat data dan informasi Kementrian Kesehatan Republik Indonesia [Internet]. 2017. Tanggal diambil: 10 Februari 2019. Tersedia pada: http:/www.depkes.go.id/download.p hp? file=download/pusdatin/lainlain/Analisis Lansia Indonesia 2017.pdf

2. Pudjiastuti S., Utomo B. Fisioterapi pada Lansia. Jakarta: EGC; 2003.

3. Lauretani F, Russo C, S. Bandinelli. Age-associated Changes in Sceletal Muscle and Their effect on Mobility : an Operational Diagnosis of Sarcopenia [Internet]. Volume 95. Journal of Applied Physiology. 2003. Tanggal diambil: 8 Maret 2019. Tersedia pada: https://www.ncbi.nlm.nih.gov/pubme d/14555665 
4. Putri Dewa Ayu Komang Trisya Artha, Purnawati S. Hubungan kekuatan otot genggam dan kemampuan fungsional pada lansia wanita di posyandu lansia Desa Dauh Puri Kelod Denpasar Barat [Internet]. 2017. Tanggal diambil: 8 Maret 2019. Tersedia pada: https://ojs.unud.ac.id/index.php/eum/ article/view/29322/18165

5. Setiati S. Geriatric medicine, sarcopenia, frailty dan kualitas hidup pasien usia lanjut: tantangan masa depan pendidikan, penelitian dan pelayanan kedokteran di Indonesia [Internet]. Volume 1, Jurnal Kedokteran Indonesia. 2013. Tanggal diambil: 24 Maret 2019. Tersedia pada:

http://staff.ui.ac.id/system/files/users/ lili.legiawati/publication/holistic peri operative management in eldery an d_geriatric patient_cs.pdf

6. Pieterse S, Manandhar M, Ismail S. The association between nutritional status and handgrip strength in older Rwandan refugees [Internet]. European Journal of Clinical Nutrition. 2008. Tanggal diambil: 17 Maret 2019. Tersedia pada: https://www.ncbi.nlm.nih.gov/pubme $\mathrm{d} / 12373611$

7. Indrawati. Pengaruh Kombinasi Terapi Latihan Range of Motion, Genggam Bola Karet dan Kompres Hangat Terhadap Kekuatan Motorik Ekstremitas Atas dan Kadar Kortisol Pada Klien Pasca Stroke di RSU Dr. Wahidin Sudiro Husodo Mojokerto
[Internet]. Repository Universitas Airlangga. 2018. Tanggal diambil: 8 Maret 2019. Tersedia pada: http://repository.unair.ac.id/78459/

8. Dewi, Risty Tegar Anita. Pengaruh Latihan Bola Lunak Bergerigi Dengan Kekuatan Genggam Tangan Pada Pasien Stroke Non Hemoragik di RSUD Prof. DR. Margono Soekarjo Purwokerto [Internet]. Repository Universitas Muhammadiyah Purwokerto. 2017. Tanggal diambil: 20 Maret 2019. Tersedia pada: http://repository.ump.ac.id/4416/3/Ri sty Tegar Anita Dewi BAB II.pdf

9. Prok W, Gessal J, Angliadi L. Pengaruh latihan gerak aktif menggenggam bola pada pasien stroke diukur dengan handgrip dynamometer. Jurnal e-Clinic [Internet]. 2016;4. Tanggal diambil: 19 Maret 2019. Tersedia pada: https://ejournal.unsrat.ac.id/index.php /eclinic/article/view/10939

10. Chaidir R, Zuardi IM. Pengaruh Latihan Range of Motion Pada Ekstremitas Atas Dengan Bola Karet Terhadap Kekuatan Otot Pasien Stroke Non Hemoragik Di Ruang Rawat Stroke RSSN Bukittinggi Tahun 2012 [Internet]. Volume 1, Jurnal Ilmu Kesehatan 'Afiyah. 2014. Tanggal diambil: 20 Maret 2019. Tersedia pada: http://ejournal.stikesyarsi.ac.id/index. php/JAV1N1/article/view/3/163 